Crop Breeding and Applied Biotechnology 15: 181-186, 2015

Brazilian Society of Plant Breeding. Printed in Brazil

NOTE

http://dx.doi.org/10.1590/1984-70332015v15n3n31

\title{
New sources of resistance to Myrothecium roridum and Podosphaeria xanthii in yellow melon
}

Elaíne Welk Lopes Pereira Nunes ${ }^{1}$, Hailson Alves Pereira Preston ${ }^{1}$, Júlio César DoVale ${ }^{2 *}$, Fernando Antônio Souza de Aragão $^{3}$, Rafaela Priscila Antônio ${ }^{4}$ and Glauber Henrique de Sousa Nunes ${ }^{1}$

Received 21 September 2014

Accepted 12 March 2015

\begin{abstract}
The aim of this study was to identify sources of resistance to Myrothecium roridum and Podosphaeria xanthii. Initially, 86 inbred lines of the crossing AM-04 x Goldex, 91 inbred lines of the crossing AM-12x Rochedo, and 75 inbred lines of the crossing ACP $x$ AF-646 were evaluated. The trials were carried out in a greenhouse in a randomized block design with five replications. Seventeen inbred lines were identified as resistant to M. roridum. These inbred lines, as well as the parents and seven differential cultivars (checks) were evaluated for the reaction to $\mathrm{P}$. xanthii. Ten inbred lines were selected as moderately resistant to $\mathrm{M}$. roridum and resistant to $\mathrm{P}$. xanthii.
\end{abstract}

Key words: Cucumis melo L., myrothecium stem canke, Oidium.

\section{INTRODUCTION}

Many factors have contributed to the decrease yield and fruit quality in melon fields, including diseases caused by pathogens that damage different parts of the plant, such as roots and leaves. The main reason for the increased incidence and severity of these diseases is the intensive and continuous cultivation of this cucurbit, often with up to three cycles per year in the same soil, associated with changes in cultural practices.

For the specific case of soil-borne pathogens, some areas are compromised due to their high population levels. Among the relevant pathogens is the fungus Myrothecium roridum, first detected in Brazil in 1991, in the agricultural region of Mossoró, State of Rio Grande do Norte (Silva et al. 1996). Since then, M. roridum has been causing severe economic loss in the Brazilian Northeast (Noronha et al. 2006). This pathogen causes superficial to deep cracks, usually crater-shaped, in the fruit. In seedlings, it causes necrosis in the lap, followed by tipping (Bruton 2004). In the leaves, it causes the disease known as myrothecium spot (Cabral et al. 2009).
Another very common melon disease is powdery mildew, which is caused by the pathogens Golovinomyces cichoracearum and Podosphaera xanthii (Kuzuya et al. 2006). The Brazilian Northeast is the largest melon-producing area in the country, where a high incidence of $P$. xanthii can cause production losses near 50\% (Delgado and Lemus 2004). However, large melon fields owned by private companies have suffered greater losses due to the low fruit quality.

Genetic resistance is an alternative for the control of both powdery mildew and Myrothecium stem canker. Advantages of this method include easy adoption by the producers, compatibility with other control methods and ecological convenience. This is because it does not bring harm to humans and to the environment. Within this context, it is first necessary to identify sources of resistance in germplasm that can be used in hybridizations in breeding programs. Thus, the aim of this study was to identify sources of resistance to $M$. roridum and $P$. xanthii.

\section{MATERIAL AND METHODS}

First trial: selection for resistance to $M$. roridum

\footnotetext{
${ }^{1}$ Universidade Federal Rural do Semi-Árido (UFERSA), Departamento de Fitotecnia, BR 110, km 47, 59.603-180, Mossoró, RN, Brazil

${ }^{2}$ Universidade Federal do Ceará (UFC), Departamento de Fitotecnia, Av. Mister Hull, 2977, Campus do Pici, 60.356-000, Fortaleza, CE, Brazil. *E-mail: juliodovale@, ufc.br

${ }^{3}$ Embrapa Agroindústria Tropical (CNPAT), Rua Dra. Sara Mesquita, 2270, Planalto do Pici, 60.511-110, Fortaleza, CE, Brazil

${ }^{4}$ Embrapa Semi-Árido, Rua Dra. Sara Mesquita, 2270, BR 428, km 152, Zona Rural, 56.302-970, Petrolina, PE, Brazil
} 


\section{Plant material and experimental design}

Firstly, the planting of the $\mathrm{S}_{0}$ population, derived from crossings involving hybrid cultivars (AM-04 x Goldex, AM-12 x Rochedo, ACP x AF-646), was carried out. AM-04 and AM-12 hybrids have fruits weighing about $1.7 \mathrm{~kg}$, with yellow and rough skin, white flesh, high levels of firmness and high total soluble solids content (12-14\%). The ACP cultivar has small fruit (600 g), smooth skin and greenishyellow pulp, high total soluble solids content (13\%) and it is moderate resistant to the fungus Didymella bryoniae. AM-04, AM-12 and ACP hybrids are used as resistance source to $M$. roridum. Goldex, Rochedo and AF-646 hybrids, which are widely cultivated in the agricultural center of Mossoró-Assu, have yellow skin, white pulp and 9-12\% total soluble solids content. Goldex and AF-646 hybrids are used as resistance source to races 1 and 2 of $P$. xanthii, while Rochedo hybrid is used as resistance source to race 1 .

From a population of 350 plants of each crossing, it began the identification of plants, and self-pollination was carried out. The advancement of generations by self-fertilization was carried out by the Single Seed Descendent (SSD) method. When the lines were in the fifth generation of selfing, an augmented block experimental design was carried out to select fruit quality, earliness and yield, leaving 121 inbred lines per crossing. Due to germination problems, it was evaluated 86 inbred lines (AM-04-G-01 to AM-04-G-86) of crossings AM-04 x Goldex, ninety-one inbred lines (AM-12-R-01 to AM-12-R-91) of crossings AM-12 x Rochedo, and 75 inbred lines (AM-ACP-01 to AM-ACP-75) of crossings ACP x AF-646.

The experiment to assess the reaction to $M$. roridum was carried out in the lap of seedlings kept in a greenhouse from May to August 2010. During the test, the temperature and relative humidity were constant $\left(27.5^{\circ} \mathrm{C}\right.$ and $65 \%$, respectively). It was used $M$. roridum isolate LE-211 obtained from a melon plant (Vereda cultivar) showing Myrothecium stem canker symptoms at the melon producing region of Mossoró-Assu. The conidia were obtained from 14-day sporing cultures grown on a PDA medium at $25 \pm 2{ }^{\circ} \mathrm{C}$ under a 12-hour light/ dark cycle.

Inoculation was carried out on 22 days-old seedlings grown on sterilized soil, and maintained in the greenhouse. Initially, the plants were injured in the lap, about $10 \mathrm{~mm}$ above the soil surface, with a pad with two entomological pins placed equidistantly at $10 \mathrm{~mm}$, producing 2-mm deep wounds. Then, the stem of each plant was inoculated with the pathogen by spraying $5 \mathrm{~mL}$ of conidial suspension (3 x $10^{6}$ conidia $\left.\mathrm{mL}^{-1}\right)$ supplemented with Tween $20(0.1 \%)$, with the aid of a DeVilbiss atomizer. Three plants of each genotype were injured and sprayed with sterile distilled water, being used as control. After inoculation, plants were kept in a moist chamber (moistened polyethylene bags) for $36 \mathrm{~h}$, and afterwards, under greenhouse conditions.

The experimental plots were constituted by pots $(0.5$ L) with three plants each, in a randomized block design. The evaluation of the reaction to Myrothecium stem canker was carried out eight days after inoculation, by removing the plants from the moist chamber and using a descriptive scale from 1 to 5 , where: 1 - no symptoms, 2 - stem lesions from 0.1 to $6.9 \mathrm{~mm}, 3$ - stem lesions $>7 \mathrm{~mm}$ without sporodochia, 4 - stem lesions $>7 \mathrm{~mm}$ with sporodochia and, 5 - plant death. The average response of each genotype was calculated by the sum of each plant ratings divided by the total number of evaluated plants. This value was used to classify the genotypes into five reaction classes, where: 1 - immune (I), 1.1 to 2.0 - highly resistant (HR), 2.1 to 3.0 moderately resistant (MR), 3.1 to 4.0 - susceptible (SU) and, 4.1 to 5.0 - highly susceptible (HS) (Noronha et al. 2006).

\section{Second trial: selection for resistance to $P$. xantii}

\section{Plant material and experimental design}

From $21^{\text {st }}$ September 2010 to $23^{\text {rd }}$ October 2010, seventeen inbred lines of yellow melon moderately resistant to $M$. roridum were evaluated: three inbred lines from crossing AM-04 x Goldex, seven inbred lines from crossing AM-12 $x$ Rochedo, and seven inbred lines from ACP x AF-646. The differential cultivars PMR 45, PMR 5, Véndratais, MR-1, Edisto 47 and PI 414723 were also included in the trial. During the trial, the temperature and relative humidity were constant $\left(27.8^{\circ} \mathrm{C}\right.$ and $61.5 \%$, respectively).

The sowing of the inbred lines was carried out in isopropylene trays with 128 cells; transplanting occurred 15 days after sowing. The trial was carried out in a completely randomized design with 10 replications. The plot consisted of one pot $(0.5 \mathrm{~L})$ with one plant. Sterilized soil was homogenized with manure to form the substrate (2:1 ratio).

Plants isolated from the commercial hybrid Yellow Queen, which is highly susceptible to oidium, were inoculated 15 days before the experiment with a race 1 isolate of the fungus, which was obtained in Mossoró-Assu. These plants were the source of the inoculum. The inoculation was accomplished by putting the conidia-infected leaf on the upper side of the third true leaf of each genotype evaluated. The isolate was obtained from a plant (Sancho cultivar) cultivated in Mossoró. The evaluation of disease severity was carried out 15 days after inoculation, using a scale that ranged from 1 to 5, where 1 - no symptoms, 2 - 
0.1 to $10 \%$ of leaf area affected, 3 - 11 to $25 \%$ of leaf area affected, $4-26 \%$ to $50 \%$ of the leaf area affected, and 5 - up to $50 \%$ of leaf area affected (Lebeda et al. 2008). Based on this classification, it is considered the inbred lines which showed no disease symptoms to $0.1-10 \%$ leaf area affected as resistant, and the inbred lines which presented more than $10 \%$ of leaf area attacked as susceptible.

\section{Estimation of genetic parameters and statistical analysis}

Analysis of variance with the effect of inbred lines as random was carried out at the end of the first trial. Genetic variance between inbred lines was estimated by the method of moments, and consequently, the heritability was also estimated. The gains with selection (GS) were obtained by the expression: $G S=d s \times h^{2}$, where $d s$ is the differential selection, and $h^{2}$ is the heritability. The nonparametric test of Kruskal-Wallis with nominal significance level of 5\% probability $(a=0.05)$ was used to analyze the data obtained in the second trial.

\section{RESULTS AND DISCUSSION}

The viability of the inoculum is a common concern in studies involving reaction of genotypes to pathogens. This concern is justified to avoid the selection of resistant and susceptible genotypes due to escaping. The ideal temperature range for $M$. roridum is between 25 and $30^{\circ} \mathrm{C}$. During this study, the average temperature was $27.5^{\circ} \mathrm{C}$. In this sense, the environmental conditions were favorable for fungal activity, evidenced by the symptoms (score $>3.7$ ) observed

Table 1. Mean values of scores and major genetic parameters of reaction to Myrothecium stem canker of the inbred lines and parents (commercials checks) in yellow melon, caused by Myrotecium roridum.

\begin{tabular}{lccc}
\hline \multirow{2}{*}{ Parents } & \multicolumn{3}{c}{ Crossings } \\
\cline { 2 - 4 } Goldex & $\begin{array}{c}\text { AM-04 x } \\
\text { Goldex }\end{array}$ & $\begin{array}{c}\text { AM-12 x } \\
\text { Rochedo }\end{array}$ & $\begin{array}{c}\text { ACP x AF- } \\
\mathbf{6 4 6}\end{array}$ \\
Rochedo & $4.15^{1}$ & - & - \\
AF-646 & - & 3.73 & - \\
AM-04 & - & - & 4.02 \\
AM-12 & 2.62 & - & - \\
ACP & - & 1.83 & - \\
\hline Inbred lines & - & - & 2.36 \\
Overall performance & $4.08^{1}$ & 3.61 & 3.87 \\
\hline$\hat{\sigma}_{G}^{2}$ & 4.13 & 3.87 & 3.89 \\
$h^{2}$ & 0.270 & 0.078 & 0.205 \\
GS & 60.67 & 27.98 & 40.95 \\
$\mathrm{n}$ & 16.06 & 5.35 & 11.92 \\
\hline
\end{tabular}

${ }^{1}$ Scores -1 to 5 according to the severity of the disease.

$\hat{\sigma}_{G}^{2}=$ genotypic variance, $\mathrm{h}^{2}=$ heritability, GS = gains with selection and $\mathrm{n}=$ population size. in parents Rochedo, AF 646 and Goldex, which were used as susceptible (Table 1). However, varying degrees of susceptibility was observed in inbred lines obtained from crossings involving these parents with other parents considered tolerant. Heritability estimates medians associated with positive selection with gains suggest that it is possible to identify inbred lines less susceptible to $M$. roridum. This can be confirmed by the proportion of intermediate resistant inbred lines obtained by the three crossings carried out between six parents (Figure 1). However, highly resistant genotypes were not observed.

In the crossing of AM-04 x Goldex parents, the majority of inbred lines obtained were classified as susceptible or highly susceptible, although AG04 was classified in this study as moderately resistant (Table 1). However, it has been rated as highly resistant in preliminaries studies (unpublished data). The severity of the disease depends on the host, pathogen and environmental conditions. In this sense, considering that the isolate preliminary used in tests to evaluate the reaction of the AM-04 parent was the same, it is very likely that this difference is due to the environment, as the same inoculation technique was used in both trials.

The AM-12 parent was rated as highly resistant in preliminary trials and in the present study. However, in the crossing involving AM-12 and Rochedo, similar behavior to the distribution of inbred lines for resistance to M. roridum was observed, when compared to the previous crossing (Figure 1). Only seven inbred lines were classified as moderately resistant, while the remaining were susceptible or highly susceptible. Finally, at the crossings between ACP and AF-646 parents, seven moderately resistant inbred lines were found. The other inbred lines, as well as the crossings AM-04 x Goldex and AM-12 x Rochedo, were also classified as susceptible or highly susceptible. In this sense, due to the low frequency of inbred lines resistant or moderately resistant detected in the crossings carried out in this study,

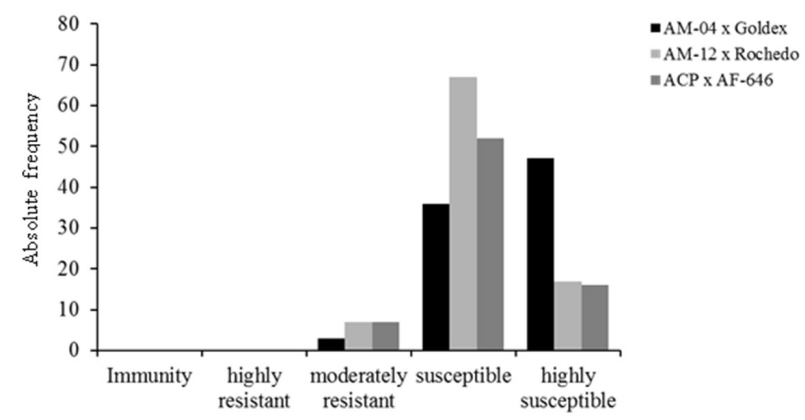

Figure 1. Absolute frequency distribution for the group reaction to Myrothecium roridum of yellow melon inbred lines obtained in three crossings. 
EWLP Nunes et al.

it appears that this trait do not have single inheritance.

With respect to genetic parameters, observed genetic variability was generated at crossings (Table 1). The AM-04 $\mathrm{x}$ Goldex and ACP x AF-646 crossings were probably the most contrasting, considering by the magnitude of genetic variances. This was directly reflected in the coefficients of heritability. As the heritability reflects the correlation between phenotypic and genotypic values, the closer to $100 \%$, the greater is the success in selecting superior genotypes (Falconer and Mackay 1996). To the present date, heritability estimates related to Myrothecium stem canker in melon or other cultures are not found in literature. The information available for $M$. roridum in melon was obtained through fruit and leaf observation. Nascimento et al. (2012) observed a heritability estimate of $65.82 \%$ for the reaction to rot crater, while Kuti et al. (1987) found coefficients below $30 \%$ on leaf reaction. In theory, heritability coefficients depend exclusively on the population and environmental conditions (Aragão et al. 2015). In this sense, estimates of other papers, even partially, help in everyday pragmatism of the breeder, and may not be totally neglected.

Heritability estimates are also useful in the selection process since they are part of the expression of the gains with genetic selection. In principle, the higher the heritability, the greater the gain with the selection, when considering the same selection intensity. This fact was verified in the present study, although the intensity of selection has not been the same for the crossings, as the selection was based on score three. The number of selected inbred lines (severity $<3.0$ ) in AM-04 x Goldex was different in relation to the other two crossings. Only three inbred lines were selected in the mentioned crossing, while seven inbred lines were selected in the other two. Furthermore, it is noteworthy that the number of tested inbred lines was not the same in all three crossings. Therefore, the gains are considered high, and are due to intermediate heritability estimates (AM-04 $\mathrm{x}$ Goldex and ACP x AF-646) and to the high selection intensity in the three crossings $(<10 \%)$.

By the results shown, it appears that the selection of resistant inbred lines to M. roridum is difficult. The inbred lines were obtained by the SSD method, which theoretically causes less losses in sampling (Surma et al. 2006). In this sense, a simple genetic control (monogenic) was expected; thus, it was obtained a larger number of highly resistant inbred lines, as well as parents. This fact is an indication that genetic control seems to be complex. Nascimento et al. (2012) found that the genetic control polygenic and oligogenic for fruit, or polygenic for leaves. However, further studies must be carried out to confirm such hypothesis.
The selected inbred lines were also evaluated for resistance to $P$. xanthii, the causal agent of powdery mildew, which is a major disease in melon plants. In the second trial, ten inbred lines $(58.8 \%)$ were resistant to powdery mildew (Table 2). These inbred lines showed almost no symptoms of the disease (score $=1$ ) on the leaves, stem or cotyledons, as well as the parents previously classified as resistant (AM-04, AM-12, and ACP). Seven inbred lines showed high severity (scores $>5.0$ ), with fungal structures (mycelium and spores) found on the abaxial and adaxial leaf surfaces, stem and cotyledons.

The isolate used in this study is not monosporic and was obtained from a single colony collected in the field from an infected leaf, at the early stage of the disease. Later, this isolate was multiplied on susceptible cucumber plants under

Table 2. Mean values for the score of reaction to $P$. xanthii in inbred lines, parents and commercial checks of yellow melon

\begin{tabular}{lccc}
\hline Genotypes & Crossings & Mean Values $^{1}$ & Reaction \\
\hline AM-04-G-01 & AM-04 x Goldex & 1.3 & Resistant \\
AM-04-G-22 & AM-04 x Goldex & 1.0 & Resistant \\
AM-04-G-35 & AM-04 x Goldex & 4.7 & Susceptible \\
AM-12-R-03 & AM-12 x Rochedo & 1.0 & Resistant \\
AM-12-R-06 & AM-12 x Rochedo & 4.7 & Susceptible \\
AM-12-R-11 & AM-12 x Rochedo & 1.4 & Resistant \\
AM-12-R-21 & AM-12 x Rochedo & 1.0 & Resistant \\
AM-12-R-26 & AM-12 x Rochedo & 1.0 & Resistant \\
AM-12-R-45 & AM-12 x Rochedo & 4.2 & Susceptible \\
AM-12-G-88 & AM-12 x Rochedo & 1.0 & Resistant \\
AM-ACP-04 & ACP x AF-646 & 3.9 & Susceptible \\
AM-ACP-12 & ACP x AF-646 & 4.6 & Susceptible \\
AM-ACP-18 & ACP x AF-646 & 4.1 & Susceptible \\
AM-ACP-21 & ACP x AF-646 & 1.5 & Resistant \\
AM-ACP-43 & ACP x AF-646 & 1.3 & Resistant \\
AM-ACP-44 & ACP x AF-646 & 4.1 & Susceptible \\
AM-ACP-58 & ACP x AF-646 & 1.0 & Resistant \\
AM-04 & & 1.0 & Resistant \\
AM-12 & & 4.0 & Susceptible \\
ACP & & 3.7 & Susceptible \\
Goldex & & 1.2 & Resistant \\
Rochedo & & 1.4 & Resistant \\
AF-646 & & 1.3 & Resistant \\
PMR 45 & & 1.0 & Resistant \\
PMR 5 & & 1.0 & Resistant \\
PI 414723 & & 1.0 & Resistant \\
MR-1 & & Resistant \\
Edisto 47 & & Resistant \\
Véndratais & & Susceptible \\
\hline$\chi^{2 a}$ & A.0 & \\
\hline Chi-square test of Kruskal-Wallis. p: probability associated & with the Kruskal- \\
Wallis test. & & \\
Mean values obtained according to Lebeda et al (2008). & \\
\hline
\end{tabular}


greenhouse conditions, far from the melon fields. Thus, it is reasonable to assume the uniformity of the considered isolate (Nicot et al. 2002). The reaction of differentials used in the present study indicates that the isolate belongs to race 1 of $P$. xanthii. This fact confirmed the results of previous tests on the race evaluation of the considered isolate. The resistance reaction of the Rochedo hybrid, resistant only to this race, also reinforces this result. This hybrid would probably be susceptible in the presence of another race.

Reis and Buso (2004) carried out a preliminary survey of $P$. xanthii races in Brazil and found 31 isolates, twentyone of which were race 1 , and eight race 2 . This showed the prevalence of race 1 in the country. Sales Junior et al. (2011) also observed the prevalence of races 1 and 2 in the agricultural center of Mossoró-Assu. Therefore, the identification of genotypes resistant to race 1 of $P$. xanthii is an important contribution to improvements in melon farming. However, considering the frequency of resistant inbred lines obtained from crossings, it can be deduced that the genetic control of resistance to this pathogen is not a simple task, as evidenced by Fazza et al. (2013). Further studies should be carried out for most consistent results, as a specific inheritance.

\section{CONCLUSIONS}

At least ten lines are moderately resistant to M. roridum, and resistant to race 1 of $P$. xanthii. These inbred lines may be used in future breeding programs for resistance to the pathogens mentioned.

\section{Novas fontes de resistências a Myrothecium roridum e Podosphaeria xanthii em melão amarelo}

Resumo - O objetivo desse estudo foi identificar fontes de resistência ao Myrothecium roridum $e$ Podosphaeria xanthii. Inicialmente, foram avaliadas 86 linhagens do cruzamento entre os cultivares AM-04x Goldex; 91 linhagens do cruzamento AM-12 x Rochedo e 75 linhagens do cruzamento ACP x AF-646, conduzidos em casa-de-vegetação, no delineamento em blocos casualizados, com cinco repetições. Foram selecionadas 17 linhagens medianamente resistentes ao M. roridum. Essas linhagens juntamente com os genitores e sete cultivares diferenciadoras (testemunhas) foram avaliadas para reação à P. xanthii em casa de vegetação, em delineamento inteiramente casualizado, com dez repetições. Dez linhagens foram selecionadas como medianamente resistentes ao M. roridum e resistentes $a$ P. xanthii.

Palavras-chave: Cucumis melo L., cancro-de-mirotécio, oidio.

\section{REFERENCES}

Aragão FAS, Nunes GHS and Queiróz MA (2015) Genotype x environment interaction of melon families base don fruit quality traits. Crop Breeding and Applied Biotechnology 15: 79-86.

Bruton BD (2004) Podredumbre del carbón. In Zitter TA, Hopkins DL and Thomas CE (Eds) Plagas y enfermedades de las cucurbitáceas. Ediciones Mundi -Prensa, Madrid, p. 9-11.

Cabral CS, Henz GP, MOREIRA AJA and REIS A (2009) New cucurbitaceous hosts of Myrothecium roridum in Amazonas State, Brazil. Tropical Plant Pathology 34: 402-405.

Delgado G and Lemus Y (2004) Taxonomía de Sphaerotheca fuliginea (Erysiphales, Ascomycota) sobre melón en Cuba. Fitosanidad 8: 27-29.

Falconer DS and Mackay TFC (1996) Introduction to quantitative genetics. $4^{\text {th }}$ edn, Longman, Malasya, $464 \mathrm{p}$.

Fazza AC, Dallagnol LJ, Fazza AC, Monteiro CC, Lima BM, Wassano DT and Camargo LEA (2013) Mapping of resistance genes to races 1, 3 and 5 of Podosphaera xanthii in melon PI 414723. Crop Breeding and Applied Biotechnology 13: 349-355.

Kuti JO, Ng TJ and Bean GA (1987) Reactions of muskmelon cultigens to Myrothecium roridum. Hortsciense 22: 635-637.
Kuzuya M, Yashiro K, Tomita K and Ezura H (2006) Powdery mildew (Podosphaera xanthii) resistance in melon is categorized into two types based on inhibition of the infection processes. Journal of Experimental Botany 57: 2093-2100.

Lebeda A, Krístková E, Sedláková B, Mccreight JD and Coffey MD (2008) New concept for determination of pathotypes and races of cucurbit powdery mildew. In Pitrat M (ed) Proceedings of the IXth EUCARPIA meeting on genetics and breeding of Cucurbitaceae, INRA, Avignon, p. 125-134.

Nascimento IJB, Nunes GHS, Sales Junior R, Silva KJP, Guimarães IM and Michereff SJ (2012) Reaction of melon accessions to crater rot and resistance inheritance. Horticultura Brasileira 30: 457-463.

Nicot PC, Bardin M and Dik AJ (2002) Basic methods for epidemiological studies of powdery mildews: culture and preservation of isolates, production and delivery of inoculum, and disease assessment. In Bélanger RR, Bushnell WR, Dik AJ and Carver TLW (eds) The powdery mildews: a comprehensive treatise. APS Press, St. Paul, p. 56-65.

Noronha MA, Michereff SJ, Xavier Filha MS, Moreira PAA, Reis A and Sales Junior R (2006) Avaliação da resistência a Myrothecium roridum em genótipos de meloeiro. Horticultura Brasileira 24: 495-498.

Reis A and Buso JA (2004) Levantamento preliminar de raças de 
EWLP Nunes et al.

Sphaerotheca fuliginea no Brasil. Horticultura Brasileira 122: 628-631.

Sales Júnior R, Nunes GHS, Michereff SJ, Pereira EWL and Guimarães IM (2011) Reaction of families and lines of melon to powdery mildew. Horticultura Brasileira 29: 382-386.
Silva DMW, Menezes M, Oliveira SMA and Pereira GF (1996) Ocorrência de Myrothecium roridum em melão em Mossoró, Rio Grande do Norte. Fitopatologia Brasileira 21: 519.

Surma M, Adamski T, Kaczmarek Z and Czajka S (2006) Phenotypic distribution of barley SSD lines and doubled haploids derived from F1 and F2 hybrids. Euphytica 149: 19-25. 